Okur, A. ve Dağtaş, A. (2014). Ortaokula yönelik kelime öğretimi çalışmaları. Ana Dili Eğitimi Dergisi, 2(4), 66-84.

Ana Dili Eğitimi Dergisi
Journal of Mother Tongue Education
ADED - JOMTE
www.anadiliegitimi.com

\title{
Ortaokula Yönelik Kelime Öğretimi Çalışmaları
}

\author{
Alpaslan Okur* \\ Abdullah Dağtaş ${ }^{*}$
}

\begin{abstract}
Özet
Bu araştırmanın amacı, ortaokula yönelik kelime öğretimiyle ilgili yapılan çalışmalarda değinilen konular, kullanılan yöntemler, veri toplama ve analiz süreçleri ile bulgu/sonuç ve önerilerin neler olduğunu tespit etmektir. Bu doğrultuda 2005-2014 arasında yayımlanan, literatür taraması şeklindeki araştırmalar hariç ve tam metin olarak elde edilen toplam 27 araştırma incelenmiştir. Inceleme sonucunda, genel olarak en çok deyimlerin öğretiminin araştıııldığı, bunu, çeşitli yöntem ve tekniklerin kelime öğretimine etkilerine dair araştırmaların takip ettiği, Türkçe Dersi Öğretim Programı'nı kelime öğretimi açısından inceleyen araştırmaların sayısının oldukça az ve benzer araştırmalarda, yöntem noktasında tutarsızlıkların bulunduğu sonuçlarına ulaşılmış ve önerilerde bulunulmuştur.
\end{abstract}

Anahtar Kelimeler: Türkçe öğretimi. Kelime hazinesi. Kelime öğretimi çalışmaları.

\section{Secondary School Oriented Word Teaching Studies}

\begin{abstract}
Objective of this research is to determine what mentioned subjects, used methods, data collection and analysis processes and finding/result and suggestions in executed studies are regarding secondary school oriented word teaching. Accordingly, totally 27 research have been examined which were received as full text and excluding literature based researches that were published between 2005-2014. In the conclusion of the study, some suggestions have been made and the following results have been obtained: Idiom teaching is the most widely researched subject. And it is followed by the researches about the effects of the various methods and techniques on vocabulary teaching. The number of the researches, which examines Turkish Language Teaching Program in terms of vocabulary teaching is very few and in the similar researches, there are some inconsistencies at the method points.
\end{abstract}

Key Words: Turkish education. Vocabulary. Word teaching studies.

\footnotetext{
*Doç. Dr., Sakarya Üniversitesi, Eğitim Fakültesi, Türkçe Eğitimi Bölümü. Sakarya, e-mektup: aokur@sakarya.edu.tr.

*Doktora Öğrencisi, Sakarya Üniversitesi, Eğitim Bilimleri Enstitüsü. Sakarya, e-mektup: abdullahdagtas@hotmail.com.
} 


\section{Giriş}

“Dil insanlar arasında anlaşmayı sağlayan tabiî bir vasıta, kendine mahsus kanunları olan ve ancak bu kanunlar çerçevesinde gelişen canlı bir varlık, temeli bilinmeyen zamanlarda atılmış bir gizli antlaşmalar sistemi, seslerden örülmüş içtimâî bir müessesedir" (Ergin, 2004: 3). "Bir tabiî iletişim vasıtası, değişen, gelişen canlı bir varlık, bir sistem ve içtimâî bir müessese" olarak tanımda ortaya çıkan özellikleri, dilin birçok yönleri olan büyük bir yapı olduğunu göstermektedir. Bu yapı içerisinde de "zihinde belli bir kavramı karşılayan veya kavramlar arasındaki ilişkiyi sağlayan ve bağlam içerisinde kullanılmaya hazır -çekimlenmemiş- birimler" (Kurudayıoğlu ve Karadağ, 2005: 305) şeklinde tanımlanan kelimeler, birer tamamlayıcı unsur olarak bu yapının önemli bir bileşenidir.

“insanın bilgi, kültür ve düşünme kabiliyetinin hududu, bildiği kelimelerin miktarı ile çizilmiştir" (Hacıeminoğlu, 2011: 14). "Bir bireyin kullandığı ya da bir bütüncede yer alan sözcüklerin tümü" (Vardar, 2002: 182) ya da "bireyin öğrenme yaşantısı sonucunda bellekte depolanan birikimi" (Özbay ve Melanlıoğlu, 2008: 33) olarak tanımlanan kelime hazinesinin geniş olması, insanın hayatını çevreleyen bütün varlık, olay ve olguları daha geniş bir bakış açısından ele almasını sağlayacaktır. "Bilindiği gibi kelimeler çeşitli anlam ve düşünceler içermekte, düşünce zincirinin halkalarını oluşturmaktadır... Çok sayıda kelime bilme birey için hazır bir güç olmakta ve başarısını artırmaktadır" (Güneş, 2013: 2).

İnsan hayatında böyle bir öneme sahip olan kelime hazinesi, okul öncesi eğitimle planlı bir şekilde genişletilmeye başlanır. illköğretimle de bu süreç daha ileri bir aşamaya geçer, ortaokulla birlikte de özelde Türkçe derslerinin bünyesinde gerçekleştirilen sistematik bir süreç hâlini alır. 11-16 yaşlarını kapsayan ortaokul yılları, literatürde soyut işlemler dönemi, erinlik ve son çocukluk dönemi gibi isimlerle anılmaktadır. Özbay’a (2011: 125) göre "Soyut düşünme evresi 11-12 yaş dolayında başlar ve bunun iki evresi vardır:

1.Öğrenci, nesneyi ve olayı görmeden de bunlar hakkında düşünebilir ve kavram geliştirebilir.

2.Öğrenci, kendi düşüncelerini eleştirmeye ve bunların üzerinde düşünmeye başlar." Bu dönemde "Mantıksal düşünme, yetişkinlerin düzeyine ulaşmıştır. Çocuklar, soyut düşünür, genellemeler yapar ve soyut kavramları kullanarak bir durumdan diğer duruma geçebilirler. "Tümevarım" ve "tümdengelim" düşünce yöntemlerini kullanabilirler" (Uludağ, 2010: 14). Başka bir deyişle bu dönemdeki öğrenciler, temel anlamlarından ziyade artık kelimelerin mecaz, yan, terim gibi farklı anlamlarını öğrenebilmekte, bunları yeri geldikçe farkında olarak yazılarında ve konuşmalarında kullanabilmektedir. Okudukları ve dinledikleri metinlerde de kelimelerin bu anlamsal boyutlarını anlayabilmektedir. 


\section{Ortaokula Yönelik Kelime Öğretimi Çalışmaları}

Literatürde Baş ve Karadağ’ın (2012) yurtdışındaki en temel ve ülkemizdeki sıklık tespiti yapan kelime öğretimi çalışmalarını ele aldıkları bir çalışmaları bulunmaktadır. Bu bağlamda bu araştırmanın amacı, ortaokula yönelik kelime öğretimiyle ilgili yapılan araştırmaları çeşitli başıklar altında incelemektir.

\section{Yöntem}

Araştırma, nitel araştırma olarak tasarlanmış ve araştırmada, doküman incelemesi tekniği kullanılmıştır. "Doküman incelemesi, araştırılması hedeflenen olgu veya olgular hakkında bilgi içeren yazılı materyallerin analizini kapsar" (Yıldırım ve Şimşek, 2011: 187).

Aynı zamanda incelenen araştırmaların kapsamı, "Ulusal Akademik Ağ ve Bilgi Merkezi", "Asos İndex", "Çukurova Üniversitesi-Makale Bilgi Sistemi" ve "Google Scholar"da taranan araştırmalar ile sınırlandırılmıştır. Bu kaynaklardan "kelime öğretimi, sözcük öğretimi, kelime hazinesi, sözcük hazinesi, söz dağarcığı, kelime dağarcığı" anahtar kelimeleri ile kelime öğretimiyle ilgili araştırmalar taranmıştır. Tarama sonucu ulaşılan araştırmalar, 2005-2014 tarihleri arasında yayımlanmış olma, literatür taraması olmama ve tam metin olma ölçütlerine göre seçilmiştir. Geriye 25 tanesi makale, 1 tanesi kurultay bildiri tam metni ve 1 tanesi de kitap bölümü olan toplam 27 araştırma kalmıştır.

Daha sonra araştırmalardan elde edilen veriler, betimsel olarak analiz edilmiştir. "Bu tür analizde amaç, elde edilen bulguları düzenlenmiş ve yorumlanmış bir biçimde okuyucuya sunmaktır. Bu amaçla elde edilen veriler, önce sistematik ve açık bir biçimde betimlenir. Daha sonra yapılan bu betimlemeler açıklanır ve yorumlanır, neden-sonuç ilişkileri irdelenir ve birtakım sonuçlara ulaşılıı" (Yıldırım ve Şimşek, 2011: 224). Veriler; konu, yöntem, çalışma grupları/örneklem, veri toplama araçları, verilerin analizi, ulaşılan bulgular/sonuçlar ve öneriler başlıkları altında incelenmiştir.

\section{Bulgular}

\section{Araştırmaların Konuları}

İncelenen araştırmaların 16 tanesi, öğrenci, Türkçe öğretmenleri ve adaylarının katılımıyla yapılan araştırmalardır. Bununla birlikte bir araştırmaya öğrenci ve Türkçe öğretmenleri katıldığından bu araştırma, her iki konu başlığı altında yer verilmiştir. Araştırmalarda (Benzer, 2013; Canbulat ve Dilekçi, 2013; Çetinkaya, 2005; Çocuk, 2012; Göçer, 2012; Gülsoy ve Uçgun, 2013; Kara, Kayabaşı ve Alkayış, 2006; Karadağ ve Kurudayıoğlu, 2010; Karadüz ve Yıldırım, 2012; Özbay, Büyükikiz ve Uyar, 2011; Özdener ve Satar, 2013; Özkan, 2013; Varışoğlu, Şerek, Gedik ve Yılmaz, 2014; Yaman ve Gülcan, 2009; Yıldız ve Okur, 2010; Yılmaz ve Doğan, 2014), Tablo 1'de gösterilen konular incelenmiştir. 
Tablo 1: Öğrenci, Türkçe Öğretmeni ve Adaylarının Katılımıyla Yapılan Araştırmaların Konuları

\begin{tabular}{lc}
\hline Konular & Sayı \\
\hline Çeşitli yöntem ve tekniklerin kelime öğretimine etkisi & 3 \\
Çeşitli değişkenlerin yazılı anlatımda kullanılan kelime hazinesine etkisi & 1 \\
Türkçe ders kitabında yer alan metinlerdeki kelimelerin öğrenciler tarafından bilinme düzeyi & 1 \\
Öğrencilerin yazılı anlatımlarında en sık kullandıkları kelimelerin yapısı & 1 \\
Türkçe ders kitabından belirlenen kelimelerin öğrencilere öğretimi ve iç sözlüğe alınabilirliği & 1 \\
Öğrencilerin kalıp sözleri kullanma düzeyleri & 1 \\
Türkçe ders kitaplarındaki metinlerde öğrencilerin anlamını bilmedikleri kelimelerin tespiti & 1 \\
Bilgisayar destekli dil öğretiminde yer alan kelime öğretimindeki sözel geribildirim türlerinin etkisi & 1 \\
Öğrencilerin deyimlerle ilgili sahip oldukları temel bilgiler, deyimleri kullanabilme durumları, algılama & 2 \\
farklılıkları & 2 \\
Deyimlerin, atasözlerinin öğretiminde gösteri ile karikatür tekniğinin kullanımı & 2 \\
Türkçe öğretmeni adaylarının deyimlere ilişkin bilgileri & 1 \\
Türkçe öğretmenlerinin kelime öğretimini nasıl gerçekleştirdikleri, karşılaştıkları sorunlar ve görüşleri & 2 \\
Toplam & 17 \\
\hline
\end{tabular}

İncelenen araştırmalardan 8 tanesi, doğrudan Türkçe ders ve çalışma kitaplarıyla yapılan araştırmalardır. Bununla birlikte Türkçe Dersi Öğretim Programı'yla ilgili ve öğrenci ile Türkçe öğretmenleri ve adaylarının katıldığı araştırmaların 5 tanesi de yine Türkçe ders ve çalışma kitaplarını kapsamaktadır. Türkçe ders ve çalışma kitaplarıyla ilgili yapılan bütün araştırmalarda (Benzer, 2013; Canbulat ve Dilekçi, 2013; Gündoğdu, 2012a; Gürbüz, 2012; Kurtoğlu ve Uçar, 2011; Kurudayıoğlu ve Karadağ, 2006; Mert, 2013a, b; Sağlam, 2013; Özkan, 2013; Ülper ve Karagül, 2012; Yaman ve Akkaya, 2014; Yılmaz ve Doğan, 2014), Tablo 2'deki konular incelenmiştir.

Tablo 2: Türkçe Ders ve Çalışma Kitaplarıyla IIIgili Yapılan Araştırmaların Konuları

\begin{tabular}{lc}
\hline Konular & Sayı \\
\hline Türkçe ders kitabındaki yabancı kökenli kelimelerin tespiti & 1 \\
Türkçe çalışma kitabındaki kelime öğretimi etkinliklerinin çeşitli değişkenlere göre incelenmesi & 1 \\
Türkçe çalışma kitaplarındaki bağlam temelli etkinliklerin bağlam türlerine göre incelenmesi & 1 \\
Ders kitabı yazarlarının kelime öğretimi çalışmalarına yönelik görüşleri & 1 \\
Türkçe çalışma kitaplarındaki kelime öğretimi etkinliklerinin düzeyi ve bunların sistemli bir çalışma & 1 \\
ürünü olup olmadığı & 1 \\
Türkçe etkinlik kitaplarındaki etkinliklerin seçiminde eğitsel oyun türlerine yeterince yer verilip & 1 \\
verilmediği & 1 \\
Türkçe ders kitaplarındaki kelime hazinesinin dilbilime ait yöntemlerle incelenmesi & 1 \\
Türkçe ders ve çalışma kitaplarında yer alan metin ve etkinliklerdeki sözcüksel görünümün belirli & 1 \\
ölçütlere göre incelenmesi & 1 \\
Türkçe ders kitaplarındaki kalıp sözler & 1 \\
Türkçe ders kitaplarındaki kelimelerin sayısı & 1 \\
Türkçe ders kitabındaki temaların sahip oldukları sözcük ortalamalarının durumu & 1 \\
Türkçe ders kitaplarındaki ortak kelime hazinesinin tespiti ve bu ortak kelime hazinesinin, & 1 \\
öğrencilerin kelime hazinesine uygunluğu & \\
Türkçe çalışma kitaplarındaki kelime öğretimi etkinliklerinin tespiti ve bu sınıflara ait ders & 1 \\
kitaplarındaki metinlerde anlamı bilinmeyen kelimelerin metin ve etkinliklerdeki yinelenme sıklığı \\
\begin{tabular}{l} 
Toplam \\
\hline
\end{tabular}
\end{tabular}

Türkçe Dersi Öğretim Programı ilgili yapılan araştırmalarda da (Demir ve Melanlıoğlu, 2011; Gündoğdu, 2012b; Mert, 2013b) Tablo 3'teki konular incelenmiştir. 


\section{Ortaokula Yönelik Kelime Öğretimi Çalışmaları}

Tablo 3: Türkçe Dersi Öğretim Programı'yla ilgili Yapılan Araştırmaların Konuları

\begin{tabular}{lc}
\hline Konular & Sayı \\
\hline Programın kavram öğretimi açısından incelenmesi & 1 \\
6, 7 ve 8. sınıf Türkçe Dersi Öğretim Programı’nda yer alan kazanımların kelime öğretimi açısından & 1 \\
değerlendirilmesi & \\
Türkçe Dersi Öğretim Programı ve Türkçe Sözlük incelenerek öğrencilere hangi deyimlerin ve bu & 1 \\
deyimlerin çağrışımla nasıl öğretileceği & 3 \\
Toplam &
\end{tabular}

\section{Araştırmaların Yöntemleri}

Araştırmaların yöntemleri incelendiğinde, öğrenci, Türkçe öğretmeni ve adaylarının katılımıyla yapılan araştırmalarda Tablo 4'teki yöntemler kullanılmıştır.

Tablo 4: Öğrenci, Türkçe Öğretmeni ve Adaylarının Katılımıyla Yapılan Araştırmaların Yöntemleri

\begin{tabular}{lc}
\hline Yöntemler & Sayı \\
\hline Ön test son test kontrol gruplu deneysel model & 5 \\
Betimsel-tarama modeli & 4 \\
Karma model & 1 \\
Eylem araştırması & 1 \\
Yarı deneysel desen & 1 \\
Yöntemi belli olmayanlar & 4 \\
Toplam & 16 \\
\hline
\end{tabular}

Türkçe ders ve çalışma kitaplarıyla ilgili yapılan araştırmalarda ise Tablo 5'teki yöntemler kullanılmıştır.

Tablo 5: Türkçe Ders ve Çalışma Kitaplarılıla Ilgili Yapılan Araştırmaların Yöntemleri

\begin{tabular}{lc}
\hline Yöntemler & Sayı \\
\hline Betimsel tarama & 4 \\
Alan araştırması & 1 \\
İçerik çözümleme & 1 \\
Dilbilime ait yöntemler & 1 \\
Doküman incelemesi & 2 \\
Genel tarama & 1 \\
Nitel tarama & 1 \\
Doküman incelemesi ve tarama & 1 \\
Yöntemi belirtilmeyen & 1 \\
Toplam & 13 \\
\hline
\end{tabular}

Türkçe Dersi Öğretim Programı'yla ilgili yapılan araştırmalarda da Tablo 6'daki yöntemler kullanılmıştır.

Tablo 6: Türkçe Dersi Öğretim Programı́yla ilgili Yapılan Araştırmaların Yöntemleri

\begin{tabular}{lc}
\hline Yöntemler & Sayı \\
\hline İçerik analizi & 1 \\
Doküman incelemesi & 1 \\
Betimsel Analiz & 1 \\
Toplam & 3 \\
\hline
\end{tabular}




\section{Araştırmalarda Belirlenen Çalışma Grupları/Örneklemler}

Incelenen araştırmalar öğrenci, Türkçe öğretmenleri ve adaylarının katılımıyla yapılan araştırmalar olduğundan bu araştırmalara, çalışma grubu veya örneklem olarak 6,7 ve 8 . sınıf öğrencileri, Türkçe öğretmenleri ve adayları katılıı̧lardır. Bu araştırmalardaki çalışma grupları veya örneklemler Tablo 7'de gösterilmiştir.

Tablo 7: Öğrenci, Türkçe Öğretmeni ve Adaylarının Katılımıyla Yapılan Araştırmalarda Belirlenen Çalışma Grupları/Örneklemler

\begin{tabular}{lc}
\hline Çalışma Grubu/Örneklemler & Sayı \\
\hline 6. sınıflar & 4 \\
7. sınıflar & 4 \\
8. sınıflar & 3 \\
1-8. sınıflar & 1 \\
6 ve 8. sınıflar & 1 \\
6 ve 7. sınıflar & 1 \\
Türkçe öğretmenleri & 2 \\
Türkçe öğretmeni adayları & 1 \\
Toplam & 17 \\
\hline
\end{tabular}

İncelenen araştırmalardan 8 tanesi, doğrudan Türkçe ders ve çalışma kitaplarıyla yapılan çalışmalardır. Bu araştırmaların 4 tanesinde incelenen kitaplar, örneklem veya çalışma grubu olarak belirtilmemiştir. Diğer araştırmalarda ise incelenen kitaplar veri kaynağı, evren ve örneklem, katılımcı kümesi gibi isimlerle belirtilmiştir. Yine bir araştırmada, incelenen Türkçe ders kitabının yayınevinin ne olduğu belirtilmemiştir. Bunlarla birlikte bütün araştırmalardaki evren ve örneklemin hangi Türkçe ders ve çalışma kitabına yönelik olduğu Tablo 8'de gösterilmiştir.

Tablo 8: Ders ve Çalışma Kitaplarının Evren ve Örneklemi

\begin{tabular}{ll}
\hline Evren ve Örneklem & Sayı \\
\hline 8. sınıf Türkçe ders kitabı & 1 \\
MEB 6. sınıf Türkçe çalışma kitabı & 1 \\
MEB 6. sınıf Türkçe ders kitabı & 1 \\
Özel 5, 6, 7 ve 8. sınıf Türkçe ders kitapları & 1 \\
Özel ve MEB 5. sınıf Türkçe etkinlik kitapları & 1 \\
MEB 6, 7 ve 8. sınıf Türkçe çalışma kitapları & 1 \\
Özel ve MEB 1-8. sınıflar Türkçe ders kitapları & 1 \\
Özel ve MEB 8. sınıf Türkçe ders kitapları & 1 \\
Özel 8. sınıf Türkçe ders ve çalışma kitapları & 1 \\
Özel ve MEB 7. sınıf Türkçe ders kitabı & 1 \\
MEB 8. sınıf Türkçe ders kitabı & 1 \\
Özel 6, 7 ve 8. sınıf Türkçe ders ve çalışma kitapları & 1 \\
Özel ve MEB 6, 7 ve 8. sınıf Türkçe ders ve çalışma kitapları & 1 \\
Toplam & 13 \\
\hline
\end{tabular}

Türkçe Dersi Öğretim Programı́yla ilgili yapılan araştırmalarda ise çalışma grubu/evren ve örneklem belirtilmemiştir. Bu araştırmalarda, çalışma grubunun/evren ve örneklemin, programın kendisinin ve bir çalışmada da programla birlikte incelenen Türkçe Sözlük'ün olduğu söylenebilir. 


\section{Ortaokula Yönelik Kelime Öğretimi Çalışmaları}

\section{Araştırmalarda Kullanılan Veri Toplama Araçları}

Incelenen araştırmalardan öğrenci, Türkçe öğretmenleri ve adaylarının katılımıyla yapılan araştırmalarda veri toplama araçlarının tamamı, Tablo 9'da gösterilmiştir.

Tablo 9: Öğrenci, Türkşe Öğretmeni ve Adaylarının Katılımıyla Yapılan Araştırmaların Veri Toplama Araçları

\begin{tabular}{ll}
\hline Veri Toplama Araçları & Sayı \\
\hline Okuma metinleri & 2 \\
Çalışma, alışırma yaprakları & 2 \\
Akademik başarı testi & 1 \\
Kişisel bilgi formu & 1 \\
Yazılı anlatımdan elde edilen kelime sıklık listeleri & 2 \\
Kelime testleri & 5 \\
Karikatürler & 1 \\
Okuma kitapları & 1 \\
Uygulama dosyası & 1 \\
Görüşme, ses kayıı cihazı, & 1 \\
Deyimleri algılama testi & 1 \\
Atasözleri ve deyimleri öğrenme başarı testi & 1 \\
Deyimleri tahmin etme ölçeği & 1 \\
Yarı yapılandırılmıs görüşme formu & 1 \\
Bilgisayar destekli dil öğretim materyalleri & 1 \\
Söylem tamamlama testi & 1 \\
Toplam & 23 \\
\hline
\end{tabular}

Türkçe ders ve çalışma kitaplarılla ilgili yapılan araştırmaların altısında ise Türkçe ders ve çalışma kitaplarının yanı sıra veri toplama aracı olarak kontrol listesi, kaynak taraması, Nooj programı, sözcüksel görünüm ölçütleri, görüşme ve kelime değerlendirme formu kullanılmıştır. Diğerlerinde ise veri toplama araçları doğrudan Türkçe ders ve çalışma kitapları olarak görülmektedir.

Türkçe Dersi Öğretim Programı́yla ilgili yapılan çalışmaların birinde de verilerin kaynak taraması ile toplandığı belirtilmektedir. Ancak üç çalışmada da Türkçe Dersi Öğretim Programı, birinde de programla birlikte Türkçe Sözlük'ün doğrudan veri toplama aracı olarak kullanıldığı görülmektedir.

\section{Araştırmalarda Toplanan Verilerin Nasıl Analiz Edildiği}

Öğrenci, Türkçe öğretmenleri ve adaylarının katılımıyla yapılan araştırmalarda nicel ve nitel verilerin nasıl analiz edildiği, Tablo $10^{\prime}$ da gösterilmiştir.

Tablo 10: Öğrenci, Türkçe Öğretmenleri ve Adaylarının Katılımıyla Yapılan Araştırmalarda Kullanılan Veri Analizi Teknikleri

Nicel Verilerin Analizinde Kullanılan Teknikler Nitel Verilerin Analizinde Kullanılan Teknikler

Varyans analizi (ANOVA)

Mann-Whitney U Testi

Kruskall Wallis H Testi

T-testi

Frekans ve yüzde analizi

Post hoc çözümleme teknikleri
Doküman analizi

Betimsel analiz

Kodlama

Gruplandırma 
Tablo 10: (Devamı) Öğrenci, Türkçe Öğretmenleri ve Adaylarının Katılımıyla Yapılan Araştırmalarda Kullanılan Veri Analizi Teknikleri

Tanımlayıcı istatistiksel yöntem

Simple Concordance

Nitel Verilerin Analizinde Kullanılan Teknikler

Nicel Verilerin Analizinde Kullanılan Teknikler

Microsoft excel

Özel bir yöntem

Türkçe ders ve çalışma kitaplarıyla ilgili yapılan araştırmalarda da elde edilen nitel ve nicel verilerin hangi tekniklerle analiz edildiği Tablo 11'de gösterilmiştir.

Tablo 11: Türkçe Ders ve Çalışma Kitaplarıyla ilıili Çalışmalarda Kullanılan Veri Analizi Teknikleri

\begin{tabular}{ll}
\hline Nitel Verilerin Analizinde Kullanılan Teknikler & Nicel Verilerin Analizinde Kullanılan Teknikler \\
\hline Kodlama & Mann-Whitney U Testi \\
İçerik Çözümlemesi & Kruskall Wallis H Testi \\
Derlem dilbilim araçları ve eleştirel söylem çözümlemesi & Frekans ve Yüzde Analizi \\
Etimolojik inceleme & Çapraz Analiz \\
Gözlem ve doküman incelemesi & Simple Concordance \\
Ulam ve alt ulam sınıflandırması & Microsoft Word \\
Alanyazın & Microsoft Excel \\
Gruplandırma & \\
$\begin{array}{l}\text { Veri değerlendirmesi } \\
\text { İçerik analizi } \\
\text { Tarama (Yöntemi belirtilmeyen araştırmada kullanıldığı } \\
\text { belirtilmiş) }\end{array}$ \\
\hline
\end{tabular}

Programla ilgili yapılan araştırmaların birinde ise verilerin frekans ve yüzde analiziyle ve birinde, alanyazın aracılığıyla değerlendirildiği belirtilmektedir. Diğer çalışmada ise verilerin nasıl analiz edildiği belirtilmemektedir; ancak bu çalışmada, verilerin betimsel olarak analiz edilmiş olduğu görülmektedir.

\section{Araştırmalarda Ortaya Çıkan Bulgular/Sonuçlar}

Öğrenci, Türkçe öğretmenleri ve adaylarının katılımıyla yapılan araştırmaların öne çıkan bulguları/sonuçları şunlardır:

> Alıştırma yoluyla tekrar, eğitsel oyunlar ve serbest kitap okuma yöntemleri, kelime öğretiminde geleneksel yönteme göre daha etkilidir.

$>\quad$ Deyimlerin, atasözlerinin gösteri ve karikatür tekniği ile öğretimi, kelime öğretiminde geleneksel yönteme göre daha etkilidir.

$>\quad$ Öğrencilerin deyimleri kullanabilme durumları normal seviyenin üzerindedir.

$>\quad$ Cinsiyet, okul öncesi eğitim alma, sosyoekonomik düzey ve akademik başarı değişkenlerine göre kelime öğrenimi farklılaşmaktadır.

$>\quad$ Cinsiyet ve yerleşke yeri değişkeni, kelime öğrenimi ve kelimeleri iç sözlüğe alabilmede etkilidir.

Türkçe ders kitabındaki metinlerde yer alan öğrencilerin anlamını sıklıkla bilmedikleri kelimelerin \% 60’tan fazlası, kitaplardaki kelime öğretimi çalışmalarında ele alınmamaktadır. 


\section{Ortaokula Yönelik Kelime Öğretimi Çalışmaları}

Öğrenciler, ders kitaplarındaki kalıp sözlerden daha fazla kalıp söz bilmektedir.

Kızlar, erkeklere göre deyimleri daha iyi anlamakta ve yaş ile okul başarı sırası, deyimlerin öğretiminde etkili olmaktadır.

$>\quad$ Öğrencilerin kelime hazinesi, kelime sayısı ve bunları öğrenme noktasında düşüktür.

$>\quad$ Bilgisayar destekli dil öğretimi materyallerinde kullanılan geribildirim türlerinin kelime öğretimine farklı etkileri vardır.

$>\quad$ ilkokul ve ortaokulun bütün düzeylerinde, öğrenciler yazılı anlatımlarında genel olarak 715 farklı, 325 türemiş kelime kullanmakta, 44 farklı yapım ekiyle kelime türetmektedir.

> Türkçe öğretmenleri ders kitaplarını yeterli, kelime öğretimini ise gerekli bulmaktadır.

> Türkçe öğretmenleri, ders kitaplarındaki kelime çalışmalarını yetersiz bulmaktadır.

$>\quad$ Türkçe öğretmeni adaylarının deyimleri tahmin etme yeterlilikleri bütüncül olarak düşüktür.

Türkçe ders ve çalışma kitaplarıyla yapılan araştırmalarda ise öne çıkan bulgular/sonuçlar şunlardır:

8. sınıf Türkçe ders kitabında toplam 1097 yabancı kökenli kelime bulunmaktadır ve kitaptaki metinler daha çok yabancı kökenli kelimeleri barındırmaktadır.

> 6. sınıf Türkçe çalışma kitabında, kelime öğretimi etkinlikler en çok Duygular, Okuma Kültürü, Doğa ve Evren; en az ise Atatürkçülük ve Sevgi temalarında bulunmaktadır ve dinleme/izleme ile konuşma beceri alanlarında kelime öğretimi etkinliklerine neredeyse hiç yer verilmemiştir.

$>$ 6. sınıf Türkçe ders kitabındaki altı tema ve bu temalardaki metinlerde ham kelime sayısı 20188'dir. Bu kelimelerin tekrar eden ve tek başına anlamı olmayanları çıkarıldığında geriye 2203 farklı kelime kalmaktadır. Ayrıca temalardaki kelime türleri ve anlam öbekleri ayrımında uyumsuzluk ve temalar arası kelime sayısı arasında büyük farklılıklar vardır.

8. sınıf Türkçe ders kitabındaki metinlerde yabancı sözcük oranı \%13'tür ve 8. sınıf Türkçe çalışma kitabındaki etkinliklerin \%15,8'inde, öğrencilerin sözcüğün anlamına yönelik yorum ve açıklama yapmaları sağlanmaktadır. \%12,6 oranındaki etkinlikte ise öğrencilerin yeni öğrendikleri sözcükleri kullanmalarına imkân tanınmaktadır; ancak belirlenen oranlar, yeterli düzey ve çeşitlilikte değildir.

> Ders kitabı yazarları, kitaplardaki kelime öğretimi çalışmalarını hazırlarken kendi deneyimlerinden yararlanmakta ve bu konuda bilimsel araştırma eksikliği olduğunu düşünmektedir.

$>\quad$ Öğrencilerin sıklıkla kullandıkları kelimeler, 7. sınıf Türkçe ders kitaplarındaki metinlerde bulunmamaktadır.

$>\quad$ Bağlam temelli etkinliklere yer verme hassasiyetinin en fazla olduğu kitap türü, Evren Yayınları 6. sınıf Türkçe çalışma kitabı; en az olduğu kitap türü ise, Tav Yayınları 8. sınıf Türkçe çalışma kitabıdır. 
MEB 8. sınıf Türkçe ders kitabındaki farklı kelimelerin yarısından fazlası ve özel bir yayınevine ait 8. sınıf Türkçe ders kitabındaki kelimelerin yaklaşık yarısı, kitaplarda sadece bir kere tekrar edilmektedir.

6, 7 ve 8. sınıf Türkçe çalışma kitaplarında kelime öğretimi etkinlikleri yeterli değildir ve etkinlikler, sistemli bir çalışmanın ürünü değildir.

> 6, 7 ve 8. sınıf Türkçe çalışma kitaplarında toplam 115 kelime öğretimi etkinliğine yer verilmektedir ve bu etkinliklerin \%62'si, tanımsal bilgi kazandırmaya yönelik; \%37,4'ü, bağlamsal bilgi kazandırmaya yönelik etkinliklerdir.

> 8. sınıf Türkçe ders kitabındaki temalar, öğrencilere öğretilecek sözcükler açısından uyumsuzdur ve temalar kolaydan zora ve öğrenciye görelik ilkesine göre hazırlanmamıştır.

$>\quad$ Kelime öğretimi açısından Türkçe 5. sınıf etkinlik kitaplarındaki oyuna dayalı etkinlikler oldukça azdır.

$>\quad$ Derlem temeline göre çokanlamlı eylemlerin gerçekleşmiş dil kullanımları, 1-8. sınıf Türkçe ders kitaplarında genel olarak doğru temsil edilmektedir ve kitaplardaki metinlerde, cinsiyetçi bir dünya görüşünün izleri bulunmaktadır.

D 6. sınıf Türkçe çalışma kitabında, kalıp sözlerle ilgili iki ve 8. sınıf çalışma kitabında sadece bir etkinlik vardır; fakat 5 ve 7. sınıf çalışma kitaplarında kalıp sözlerle ilgili etkinlik bulunmamaktadır.

Türkçe Dersi Öğretim Programı́yla ilgili yapılan araştırmalarda da öne çıkan bulgular/sonuçlar şunlardır:

Programda kavram öğretimine yönelik kazanımlar, bütün kazanımların \%10’unu kapsamakta ve bu kazanımlar, çoğunlukla anlama becerilerinin geliştirilmesine hizmet etmektedir.

Programında sözvarlığını zenginleştirme amacına yönelik oluşturulan kazanımlar ve etkinlik örnekleri birbiriyle uyumludur; ancak, programdaki kazanım ve etkinlikler ile 6, 7 ve 8 . sınıf Türkçe çalışma kitaplarındaki kelime öğretimi etkinlikleri birebir örtüşmemektedir.

$>$ Programda deyimlerin öğretimine, deyimlere ilişkin kazanımların neler olması gerektiğine, hangi yöntem ve teknik ile hangi sınıfta, hangi deyimlerin öğretileceğine değinilmemektedir.

\section{Araştırmalardaki Öneriler}

Öğrenci, Türkçe öğretmenleri ve adaylarının katılımıyla yapılan araştırmalarda; ezbere dayalı kelime öğretiminden ziyade çağdaş kelime öğretiminin yapılması, öğretmenlerin kelime öğretimi çalışmalarında kendilerinin de ek çalışmalar yapmaları, bilgilendirilmeleri, her sınıf seviyesine göre kelime sıklık listelerinin oluşturulması, kelimelerin birden fazla anlamının da öğrencilere öğretilmesi 


\section{Ortaokula Yönelik Kelime Öğretimi Çalışmaları}

ve kelime öğretimi konusunda daha fazla araştırma yapılması gerektiği, çalışmaların çoğunda karşımıza çıkan ortak önerilerdir.

Bunlardan başka araştırmalardaki diğer öneriler şunlardır:

Kısa aralıklı alıştırma, serbest okuma ve eğitsel oyunlar gibi yöntem ve tekniklerden kelime öğretimi çalışmalarında yararlanılmalıdır.

$>\quad$ Kelime öğretimi araştırmalarında, kelimelerin farklı anlamları da hesaba katılmalıdır.

$>\quad$ Gösteri, kavramsal anahtar gibi yöntemler, deyimlerin öğretiminde kullanılmalıdır ve deyimler, belirli yapılar içerisinde öğrencilere öğretilmelidir.

$>\quad$ Bilgisayar destekli dil öğretimi kapsamında, kelime öğretiminde animasyon, deneme sayısı ve sözel-görsel materyallerden yararlanılmalıdır.

$>\quad$ Karikatürler, kelime öğretimi ve farklı konuların öğretiminde kullanılmalıdır.

> Türkçenin kelime türetme özelliğinden kelime hazinesinin geliştirilmesinde yararlanılmalıdır.

$>\quad$ Türkçe öğretmenleri zümre veya çoklu öğrenme ortamları oluşturarak kelime öğretimi hakkında görüş alışverişi yapmalı ve farklı kelime öğretim uygulamalarını daha da azaltmalıdırlar.

$>\quad$ Deyimlerin öğretiminde dilbilimsel araştırma sonuçlarından yararlanılmalı, deyim öğretimi dilbilimsel temellere oturtulmalıdır.

> Öğrencilere kazandırılacak kelime listeleri oluşturulurken kelimelerin bilinme düzeyi tespit edilmelidir.

$>\quad$ Kelime öğretimi çalışmalarında yazıı anlatımdan başka farklı öğrenme alanları da araştırılmalara dâhil edilmelidir.

Türkçe ders ve çalışma kitaplarıyla yapılan araştırmalarda ise her sınıf seviyesine göre öğrencilerin ortak kelime hazinesinin belirlenmesi ve bu ortak kelime hazinesinin öğrencilere öğretilmesi gerektiği, birkaç çalışmada karşımıza çıkan ortak bir öneridir. Bunun dışında, araştırmalarda öne çıkan diğer öneriler şunlardır:

Türkçe ders kitaplarındaki metinlerde köken olarak Türkçe kelimelere daha fazla yer verilmeli, öğrencilerin kelimeleri kullanarak içselleştirmeleri sağlanmalıdır.

$>\quad$ Türkçe ders kitabındaki temalarda bulunan öğrencilere kazandırılacak kelimeler, onların hayatlarında karşılaştıkları kelimelerden seçilmeli ve bunların kullanım sıklığına dikkat edilmelidir.

$>\quad$ Türkçe ders kitaplarındaki metinlerde kalıp sözler daha sık kullanılmalıdır.

> Türkçe çalışma kitaplarındaki kelime öğretimi çalışmaları belirlenirken ders kitabı yazarlarından da yararlanılmalıdır. 
MEB 6. sınıf Türkçe çalışma kitabındaki Atatürkçülük ve Sevgi temalarındaki sözcük öğretimi etkinlikleri arttırılmalı ve kelime öğretimi etkinlikleri, dinleme/izleme ve konuşma alanlarını da kapsayacak biçimde genişletilmelidir.

> Türkçe ders ve çalışma kitapları, uzmanlarca özenli bir şekilde hazırlanmalı ve kitapların dili kelimeler bağlamında bilimsel çalışmalardan yararlanarak sistemli bir şekilde oluşturulmalıdır.

> Türkçe çalışma kitaplarındaki kelime öğretimi etkinlikleri arttırılmalı ve sadece kelime öğretimine yönelik etkinlik kitapları hazırlanmalıdır.

> Türkçe ders kitaplarının sınıf seviyelerine göre toplam ve farklı kelime artışları arasındaki oranları ile ders kitaplarında kelime hazinesi yönünden ölçütler, bir devlet politikası olarak belirlenmelidir.

> Ders kitaplarındaki metinlerin seçiminde pedagojik bağlamdan yararlanılmalı ve bağlam temelli kelime öğretimi etkinlikleri tüm beceri alanlarına yönelik olmalıdır.

> Türkçe ders ve çalışma kitaplarının tamamı, bağlamsal/kullanımsal bilgi kazandırmaya yönelik etkinliklerin tamamına yönelik olacak şekilde yeniden düzenlenmelidir.

$>$ 5. sınıf Türkçe etkinlik kitabındaki kelime öğretimi çalışmalarının oyun etkinlikleriyle işlevselliği arttırılmalıdır.

> Öğrencilere kazandırılacak kelime listeleri, ders kitaplarında onlara hedef olarak verilmeli ve bu kelimelerden oluşan metin ve etkinliklere ağırlık verilmelidir.

Türkçe Dersi Öğretim Programı́yla ilgili yapılan çalışmalarda da öne çıkan öneriler şunlardır:

Programda kavram öğretimi kazanımlarının anlatma becerilerinin geliştirilmesine yönelik olanları arttırımalıdır.

$>\quad$ Kelime öğretimine yönelik kazanımları gerçekleştirecek etkinlikler, programda daha kapsamlı olarak ele alınmalıdır.

$>\quad$ Programda, dil becerisi edindirmede deyimlerin de kullanımını teşvik edici düzenlemelere gidilmelidir.

> Öğrenci ve Türkçe ders kitaplarına yönelik bir araştırmadaki öneriye göre de programda, kalıp sözlerin öğretimine yönelik kazanımlar bulunmalıdır.

\section{Sonuç ve Öneriler}

"Söz varlı̆̆ı bir dilin ve dolayısıyla o dili konuşan ve yazan bireylerin anlatım gücünü geliştirir. Dilin anlatım gücü, milletin her noktadaki gücüne de tekabül eder. Söz varlığının gücünü koruyabilen ve zenginleştirebilen millet, her daim var olur" (Baş, 2010: 138). Nitekim bu araştırmada, ortaokula yönelik kelime öğretimi ile ilgili, literatüre dayalı araştırmalar hariç, 27 araştırma, çalışma konusu, 


\section{Ortaokula Yönelik Kelime Öğretimi Çalışmaları}

yöntem, çalışma grubu/örneklem, veri toplama araçları, veri analizi, bulgular/sonuçlar ve öneriler bakımından incelenmiştir.

Öncelikle konu bakımından araştırmalar incelendiğinde, öğrenci, Türkçe öğretmenleri ve adaylarının katılımıyla yapılan araştırmalarda, en çok deyimlerin öğretiminin araştırıldığı görülmektedir. Bunu, çeşitli yöntem ve tekniklerin kelime öğretimine etkileri, Tablo 1'de ayrı ayrı gösterilse de Türkçe ders kitaplarındaki metinlerden seçilen bir kelime listesinin öğretimini ve Türkçe öğretmenlerinin kelime öğretimiyle ilgili görüşlerini ortaya koyan çalışmalar takip etmektedir. Yaş, cinsiyet, akademik başarı, yerleşke türü gibi değişkenlerin ve özellikle bilgisayar yani elektronik ortamın kelime öğretimine etkilerine yönelik çalışmalar ise azdır. Bu değişkenlerin ve özellikle elektronik ortamın kelime öğretimine yönelik etkileri, daha etraflı bir şekilde araştırılabilir. Bununla birlikte sadece bir çalışmada görülen, öğrencilerin öğrendikleri kelimeleri iç sözlüklerine alabilirliğine dair daha fazla araştırma yapılabilir. Bu, öğrencilerin zihinlerinde hangi kelimeleri ne şekilde öğrendiklerinin tespit edilmesinde ve buna göre kelime öğretimi çalışmalarında önlem alınmasında yardımcı olabilir.

Türkçe ders ve çalışma kitaplarıyla ilgili araştırmalarda ise Türkçe ders ve çalışma kitaplarının kelime öğretimi açısından çeşitli noktalarda araştırıldığı görülmektedir. Ancak doğrudan Türkçe ders ve çalışma kitaplarına yönelik yapılan bu araştırmalar arasında, sadece bir çalışmada görülen ders kitabı yazarlarının kitaplardaki kelime öğretimi çalışmalarına yönelik görüşlerini ortaya koyan araştırmaların sayısı arttırılabilir. Ders kitabı yazarlarının bu konudaki görüşleri, ders ve çalışma kitapları hazırlanırken ders kitabı hazırlayıcılarına ve araştırmacılara faydalı olabilir. Yine Türkçe çalışma kitaplarındaki kelime öğretimi etkinliklerine dair öğrencilerin daha derinlemesine görüşlerini ortaya koyan araştırmalar yapılabilir. Böyle araştırmalar, kelime öğretimi etkinlikleri hazırlanırken öğrencilerin isteklerinin de neler olduğunu ortaya koyacak ve öğrencilere daha faydalı kelime öğretimi etkinlikleri hazırlanmasını sağlayacaktır.

Programla ilgili yapılan araştırmalarda da programın kavram öğretimi açısından ve programdaki kelime öğretimi etkinlikleri ile programda deyimlerin durumunun araştırıldığı görülmektedir. İlkin, programı kelime öğretimi açısından inceleyen araştırmaların sayısı azdır. Programın kelime öğretimi açısından bütün boyutları daha kapsamlı bir şekilde araştırılabilir. Ayrıca, bu araştırmalarda programın kelime öğretimi açısından eksik yanları tespit edilmekle birlikte daha önemlisi, eksik kalan yanlarının nasıl tamamlanacağı daha işlevsel örneklerle gösterilebilir. Sadece bu konuda öneri verilmesinden ziyade işlevsel örneklerin oluşturulması, programın gözden geçirilmesi veya yeniden düzenlenmesinde program hazırlayıcılarına daha faydalı olabilir. 
Yöntem bakımından incelenen araştırmalardan öğrenci, Türkçe öğretmenleri ve adaylarının katılımıyla araştırmalarda, tarama modeli ve deneysel modelin, Türkçe ders ve çalışma kitaplarında da tarama modelinin daha çok kullanıldığı görülmektedir. Bununla birlikte özellikle Türkçe ders ve çalışma kitaplarıyla ilgili araştırmalarda, benzer noktalar araştırılsa da farklı yöntemlerin kullanıldığı görülmektedir. Elbette her bir araştırma, kendi araştırma problemine uygun bir yöntem seçecektir; fakat benzer çalışmalarda farklı yöntemlerin kullanılması, yöntem noktasında bir tutarsızlığın olduğunu göstermektedir. Onun için benzer konular araştırılırken yönteme dikkat edilmesi, daha önce yapılan benzer araştırmaların yöntemlerine bakılması ve sonra araştırmaya en uygun yöntemin seçilmesi, daha nitelikli araştırmaların yapılmasını sağlayacaktır. Bir de öğrenci, Türkçe ders ve çalışma kitaplarıyla ilgili araştırmalarda, tek bir yöntem belirtilip hem öğrencilerin hem de Türkçe ders ve çalışma kitaplarının araştırma sürecine dâhil edildiği görülmektedir. Oysa iki yönlü olarak kabul edilebilecek böyle araştırmalarda, her bir araştırma yönü için ilgili yöntem ne ise onu belirtmek daha doğru olacaktır.

Çalışma grupları/örneklemler bakımından da öğrenci, Türkçe öğretmenleri ve adaylarının katııımıyla yapılan araştırmalarda, daha çok 6, 7 ve 8. sınıf öğrencilerinin katılımıyla araştırmaların yapıldığı görülmektedir. Fakat 5. sınıf öğrencilerinin katılımıyla yapılmış bir araştırma yoktur. Bunda, zorunlu eğitimin 12 yıla çıkartılması ile 5. sınıfın ortaokula eklenmesi etkili olmuştur, denilebilir. Ancak 5. sınıf öğrencilerinin katılımıyla da kelime öğretimi araştırmaları yapıımalıdır. Yine Türkçe öğretmenleri ve adaylarının katılımıyla yapılan araştırmaların az olduğu görülmektedir. Dolayısıyla Türkçe öğretmenleri ve adaylarının katılımıyla yapılan çalışmalar arttırılabilir. Hatta sınıf öğretmenleriyle Türkçe öğretmenlerinin görüşlerini birlikte ele alan araştırmalar da yapılabilir. Bu, ilkokuldaki kelime öğretimi ile ortaokulda kelime öğretimi arasında bir bağlantı kurulmasını ve Türkçe ders ve çalışma kitaplarında metin seçimi ve kelime öğretimi etkinliklerinin daha nitelikli olarak hazırlanmasını sağlayabilir.

Türkçe ders ve çalışma kitaplarıyla ilgili yapılan çalışmaların bazılarında da incelenen kitaplar çalışma grubu/örneklem olarak gösterilmemiş; diğer çalışmalarda ise incelenen kitaplar, evren ve örneklem, veri kaynağı ve katılımcı kümesi gibi isimlerle gösterilmiştir. Ayrıca bir çalışmada incelenen kitabın hangi yayınevi tarafından basıldığı belirtilmemiştir. Öncelikle, kitapların basıldığı yayınevlerinin araştırmalarda belirtilmesi gerekir; çünkü farklı yayınevlerine ait Türkçe ders ve çalışma kitapları, farklı özellikler taşımaktadır. Bundan başka Türkçe ders ve çalışma kitapları incelenirken incelenen kitapların çalışma grubu/örneklem olarak gösterilmesi, başka araştırmacılara, okuyuculara daha faydalı olacağı gibi araştırmanın niteliğini de arttıracaktır. Bu durum, programla ilgili yapılan araştırmalar için de geçerlidir. 


\section{Ortaokula Yönelik Kelime Öğretimi Çalışmaları}

Veri toplama araçları bakımından öğrenci, Türkçe öğretmenleri ve adaylarının katılımıyla yapılan araştırmalarda, çeşitli veri toplama araçlarının kullanıldığı görülmektedir. Türkçe ders ve çalışma kitaplarının çoğunda ise çeşitli veri toplama araçları kullanılmakla birlikte asıl veri toplama aracı, doğrudan Türkçe ders ve çalışma kitaplarıdır. Bu durum, Türkçe Dersi Öğretim Programı́yla ilgili yapılan araştırmalar için de geçerlidir. Tabi ki her bir araştırmacı, araştırma nesnesine uygun bir veri toplama aracı geliştirecek veya araştırma nesnesini doğrudan inceleyecektir. Ancak özellikle Türkçe ders ve çalışma kitapları ile Türkçe Dersi Öğretim Programı incelenirken daha özgün noktalarda veri toplama araçlarının geliştirilerek kitaplar ile programın incelenmesi, alana daha fazla katkı sağlayacak, farklı araştırmaların da kapısını açacaktır.

Bulgular/sonuçlar ile öneriler bakımından da bütün araştırmalarda, araştırma sonucunda ulaşılan bulgular/sonuçlar ve geliştirilen öneriler belirtilmiştir. Ancak bütün bu bulgular/sonuçlar ve öneriler, ülkemizde hâlâ kelime öğretiminde sorunların çözülmediğini, kelime öğretimi alanının büyük eksikliklerinin olduğunu göstermektedir.

Sonuç olarak kelime öğretimi, Türkçe öğretiminin en önemli boyutlarından biridir. Kelime öğretimiyle ilgili yapılacak her bir araştırma da kelime öğretiminin önemli bir yanını ortaya koyacaktır. Ancak, yukarıdaki çalışmaların önerileri arasında da bulunmakla birlikte, her bir sınıf düzeyinde öğrencilere öğretilmesi gereken kelime hazinesini, öğrenciler ve öğretmenler aracılığıyla ve Türkçenin temel eserlerinden yararlanarak oluşturmak ve buna uygun ders ve çalışma kitapları ile sözlükler hazırlamak, kelime öğretiminin en büyük sorununun çözülmesine yardımcı olacaktır.

\section{Kaynaklar}

Baş, B. (2010). Söz Varlı̆ııın Oluşumu ve Gelişiminde Çocuk Edebiyatının Rolü. Türklük Bilimi Araştırmaları Dergisi, 27, 137-159.

Baş, B. ve Karadağ, Ö. (2012). Söz Varlığı Üzerine Yurt Dışında ve Türkiye'de Yapılan Temel Araştırmalar. Milli Eğitim, 193, 81-105.

Ergin, M. (2004). Türk Dil Bilgisi. (4. baskı). İstanbul: Bayrak Basım, Yayım, Dağıtım.

Güneş, F. (2013). Kelimelerin Gücü ve Zihinsel Sözlük. Siirt Üniversitesi Sosyal Bilimler Enstitüsü Dergisi, $01,1-24$

Hacıeminoğlu, N. (2011). Türkçenin Karanlık Günleri. (6. baskı). İstanbul: Türk Edebiyatı Vakfı Yayınları. Kurudayıŏlu, M. ve Karadağ, Ö. (2005). Kelime Hazinesi Çalışmaları Açııından Kelime Kavramı Üzerine Bir Değerlendirme. GÜ, Gazi Eğitim Fakültesi Dergisi, 25(2), 293-307.

Özbay, M. (2011). Türkçe Özel Öğretim Yöntemleri I. (4. baskı). Ankara: Öncü Kitap.

Özbay, M. ve Melanlıoğlu, D. (2008). Türkçe Eğitiminde Kelime Hazinesinin Önemi. Yüzüncü Yıl Üniversitesi Eğitim Fakültesi Dergisi, 1(5), 30-45.

Uludağ, Ç. (2010). 7. Sınıf Türkçe Ders Kitaplarının Söz Varlığı Açııından Incelenmesi. Yayımlanmamış yüksek 
lisans tezi. Marmara Üniversitesi Eğitim Bilimleri Enstitüsü, İstanbul.

Vardar, B. (2002). Açıklamalı Dilbilim Terimleri Sözlüğü. (1. baskı). İstanbul: Multilingual Yayınları.

Yıldıım, A. ve Şimşek, H. (2011). Sosyal Bilimlerde Nitel Araştırma Yöntemleri. (8. baskı). Ankara: Seçkin Yayıncılık. 


\section{Ortaokula Yönelik Kelime Öğretimi Çalışmaları}

Ek 1.

incelenen Makaleler

\begin{tabular}{|c|c|c|c|c|}
\hline Sayı & Yıl & Dergi Adı & Makale Başlığı & Yazarlar \\
\hline 1 & 2012 & $\begin{array}{l}\text { The Journal of } \\
\text { Academic Social } \\
\text { Science Studies }\end{array}$ & $\begin{array}{l}\text { Illköğretim VIII. Sınıf Türkçe Ders Kitabında } \\
\text { Geçen Yabancı Kökenli Kelimeler Üzerine } \\
\text { Bir İnceleme }\end{array}$ & Adem GÜRBÜZ \\
\hline 2 & $2012 b$ & $\begin{array}{l}\text { Dicle Üniversitesi } \\
\text { Sosyal Bilimler } \\
\text { Enstitüsü Dergisi }\end{array}$ & $\begin{array}{l}\text { Türkçe Dersi Öğretim Programı'nın } \\
\text { Kavram Öğretimi Açısından Incelenmesi }\end{array}$ & Ayşe Eda GÜNDOĞDU \\
\hline 3 & $2012 a$ & $\begin{array}{l}\text { Uluslar arası Türkçe } \\
\text { Edebiyat Kültür } \\
\text { Eğitim Dergisi }\end{array}$ & $\begin{array}{l}\text { İlköğretim Altıncı Sınıf Türkçe Dersi Sözcük } \\
\text { Öğretimi Etkinliklerinin Çeşitli Değişkenler } \\
\text { Açısından İncelenmesi }\end{array}$ & Ayşe Eda GÜNDOĞDU \\
\hline 4 & 2013 & İlköğretim Online & $\begin{array}{l}\text { Kelime Dağarcığını Geliştirmede } 6 \text {. Sınıf } \\
\text { Türkçe Ders Kitabının Etkisi }\end{array}$ & Ahmet BENZER \\
\hline 5 & 2005 & Dil Dergisi & $\begin{array}{l}\text { Basit Tekrar ve Alıştırmalarla Kelime } \\
\text { Öğretimi }\end{array}$ & Zeynep ÇETINKAYA \\
\hline 6 & 2011 & $\begin{array}{l}\text { Gazi Eğitim Fakültesi } \\
\text { Dergisi }\end{array}$ & $\begin{array}{l}\text { Türkçe Öğretiminde Deyimlerin Çağrışımla } \\
\text { Öğretilmesi }\end{array}$ & $\begin{array}{l}\text { Tazegül DEMIR ve } \\
\text { Deniz MELANLIOĞLU }\end{array}$ \\
\hline 7 & $2013 a$ & TSA & $\begin{array}{l}\text { Türkçe Ders ve Çalışma Kitaplarının } \\
\text { Sözcüksel Görünümlerine İlişkin Örnek Bir } \\
\text { Uygulama }\end{array}$ & Esra Lüle MERT \\
\hline 8 & $2013 b$ & $\begin{array}{l}\text { Dil ve Edebiyat } \\
\text { Eğitimi Dergisi }\end{array}$ & $\begin{array}{l}\text { İlköğretim Türkçe Programı ile Türkçe } \\
\text { Çalışma Kitaplarındaki Kazanım ve } \\
\text { Etkinliklerin Sözcük Öğretimi Açısından } \\
\text { İncelenmesi }\end{array}$ & Esra Lüle MERT \\
\hline 9 & 2011 & $\begin{array}{l}\text { Mustafa Kemal } \\
\text { Üniversitesi Sosyal } \\
\text { Bilimler Enstitüsü } \\
\text { Dergisi }\end{array}$ & $\begin{array}{l}\text { İlköğretim Yedinci Sınıf Öğrencilerinin } \\
\text { Yazılı Anlatımlarındaki Kelime Hazineleri } \\
\text { Üzerine Bir İnceleme }\end{array}$ & $\begin{array}{l}\text { Murat ÖZBAY, Kadir } \\
\text { Kaan BÜYÜKIKIZ ve } \\
\text { Yusuf UYAR }\end{array}$ \\
\hline 10 & 2006 & $\begin{array}{l}\text { Ahi Evran } \\
\text { Üniversitesi Kırşehir } \\
\text { Eğitim Fakültesi } \\
\text { Dergisi }\end{array}$ & $\begin{array}{l}\text { Ortak Kelime Hazinesi Kazandırmada } \\
\text { İlköğretim Sekizinci Sınıf Türkçe Ders } \\
\text { Kitaplarının Durumu }\end{array}$ & $\begin{array}{l}\text { Mehmet } \\
\text { KURUDAYIOĞLU } \\
\text { Özay KARADAĞ }\end{array}$ \\
\hline 11 & 2010 & $\begin{array}{l}\text { Türklük Bilimi } \\
\text { Araştırmaları Dergisi }\end{array}$ & $\begin{array}{l}\text { Türkçedeki Kelime Türetme Özelliğinir } \\
\text { İlköğretim Öğrencilerinin Yazılı Anlatımların } \\
\text { Yansıması }\end{array}$ & $\begin{array}{l}\text { in Özay KARADAĞ ve } \\
\text { la Mehmet } \\
\text { KURUDAYIOĞLU }\end{array}$ \\
\hline 12 & 2013 & $\begin{array}{l}\text { Turkish Studies- } \\
\text { International Periodical } \\
\text { for the Languages, } \\
\text { Literature and History of } \\
\text { Turkish or Turkic }\end{array}$ & $\begin{array}{l}\text { 6. Sınıf Öğrencilerinin Kelime Hazinesinir } \\
\text { Geliştirilmesinde Eğitsel Oyunların Etkisinir } \\
\text { İncelenmesi }\end{array}$ & $\begin{array}{l}\text { in Tuba GÜLSOY ve } \\
\text { in Duygu UÇGUN }\end{array}$ \\
\hline
\end{tabular}


142014 ilköğretim Online

$15 \quad 2010$

Türklük Bilimi Araştırmaları Dergisi
İlköğretim İkinci Kademe Türkçe Ders Kitaplarında Anlamı Bilinmeyen Kelimeler için Kullanılan Bağlam Türleri

İlköğretim Okullarındaki Okuma Cemâl YILDIZ ve Etkinliklerinde Göz Ardı Edilen Bir Konu: Alpaslan OKUR Sözcük Öğretimi

Sayı Y $\quad$ Kitap Bölümü

4. Uluslar arası Türkçenin EğitimiÖğretimi KurultayıSakarya Üniversitesi, Sakarya

2013 Turkish StudiesInternational Periodical for the Languages, Literature and History of Turkish or Turkic Edebiyat Kültür Eğitim Dergisi (Editörler). Türkçe Öğretimi Üzerine Çalışmalar. s. 408420. Dokuz Eylül Üniversitesi, İzmir.

$212012 \quad$ Karadeniz (Black SeaÇernoye More) Sosyal Bilimler Dergisi Üniversitesi Sosyal Bilimler Enstitüsü Dergisi
Makale Başlığı

Sözcük Öğretimi Yaklaşımları Açısından Türkçe Ders Kitaplarının Değerlendirilmesi

Hakan ÜLPER ve Süleyman KARAGÜL

İlköğretim 8. Sınıf Türkçe Ders Kitaplarında Öğrencilere Kazandırılması Hedeflenen Sözcüklerin Öğretimi ve İç Sözlük illişkisi (Mersin İli Örneği)

Oyunların Dil Bilgisi Öğretiminde ve Kelime Serveti Etkinliklerindeki Yeri (Yenilenen İlköğretim 5. Sınıf Ders Kitapları Örneği)

Illköğretim Türkçe Ders Kitapları Derleminde Sözvarlığı Görünümleri

Özlem KURTOĞLU ve Aygül UÇAR

İlköğretim 8. Sınıf Öğrencilerinin Deyimleri Kullanma Yeterlilikleri Üzerine Bir inceleme

7. Sınıf Öğrencilerinin Anlamını Bilmedikleri Kelimeler ve Türkçe Ders Kitaplarındaki Kelime Çalışmaları Bağlamında Kelime Öğretimi

Kelime Hazinesinin Geliştirilmesinde Öğretmenlerin Görüş ve Uygulamaları

Adnan KARADÜZ ve ilayda YILDIRIM
Gaziantep Üniversitesi Sosyal Bilimler Enstitüsü Dergisi 


\section{Ortaokula Yönelik Kelime Öğretimi Çalışmaları}

$23 \quad 2013$

Turkish StudiesInternational Periodical for the Languages, Literature and History of Turkish or Turkic

Pamukkale Üniversitesi Eğitim Fakültesi Dergisi

Illköğretimde Kullanılan Deyimlere İlişkin Bir Araştırma

Türkçe Ders Kitaplarındaki Kalıp Sözler ve Öğrencilerin Kalıp Sözleri Kullanma Düzeyleri$$
\text { (n) }
$$

Bilgisayar Destekli Dil Öğretiminde Kelime Çalışmaları ve Sözel Geribildirim Kullanım Teknikleri

$262014 \quad$ Karadeniz Araştırmaları

Deyim ve Atasözlerinin Öğretilmesinde Görsel Bir Araç Olarak Karikatürlerin Başarıya Etkisi

$272012 \quad$ Mersin Üniversitesi Eğitim Fakültesi Dergisi
Öğretmen Adaylarının Deyimleri Anlamsal Açıdan Tahmin Edebilirlikleri: Mersin Üniversitesi Örneği
Mehmet CANBULAT ve Atilla DiLEKÇi

Ahmet KARA, Bekir KAYABAŞI ve M. Fatih Alkayış

Nesrin ÖZDENER ve $H$. Müge SATAR

B. VARIŞOĞLU, i. ŞEREF, M. GEDIK ve i. YILMAZ

Halil Erdem ÇOCUK 